\title{
紀伊山地上流に位置する猿谷ダムにおける 水質・植物プランクトンの長期変化
}

\author{
LONG-TERM VARIATIONS OF WATER QUALITY AND PHYTOPLANKTON IN \\ SARUTANI DAM IN STREAM BASIN IN THE KII MOUNTAINS
}

\author{
石塚正秀 ${ }^{1} \cdot$ 寺本健士 $^{2} \cdot$ 海原健吾 $^{3} \cdot$ 紺野雅代 $^{2} \cdot$ 清家志乃 $^{2} \cdot$ 井伊博行 $^{4} \cdot$ 平田健正 ${ }^{5}$ \\ Masahide ISHIZUKA, Takeshi TERAMOTO, Kengo KAIHARA, Masayo KONNO, Sino SEIKE, Hiroyuki II \\ and Tatemasa HIRATA

\begin{tabular}{|c|c|c|c|c|}
\hline${ }^{1}$ 正会員 & 博(工) & 和歌山大学助手 & システム工学部環境システム学科 & （テ640-8510 和歌山市栄谷 $930 ）$ \\
\hline 2学生会員 & & 和歌山大学大学院 & システム工学研究科システム工学専攻 & （广640-8510 和歌山市栄谷 930$)$ \\
\hline & & 和歌山大学 & システム工学部環境システム学科 & （厂640-8510 和歌山市栄谷 $930 ）$ \\
\hline & 博(理) & 和歌山大学教授 & システム工学部環境システム学科 & （厂640-8510 和歌山市栄谷930） \\
\hline & 工博 & 和歌山大学教授 & システム工学部環境システム学科 & 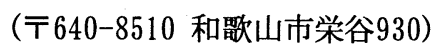 \\
\hline
\end{tabular}

Loss of water quality is proceeding in reservoirs and dams, even in stream basins near mountaintops, where is little artificial influence of nutrients. This paper presents water quality data, including phytoplankton data, that were observed from 1976 at the Sarutani Dam in the upper reach of Kinokawa River basin. A salient result is that dissolved oxygen in the bottom layer was less than $10 \%$ in 1976. This result means that not only a small supply of nutrients from natural sources such as soil, leaves, and branches, but also internal production has a large influence on water quality in the reservoir. Even though the T-N concentration is almost equal inside the reservoir and in the upper reaches of the stream, the ON/T-N ratio was large in the reservoir. This result indicates that internal production caused by phytoplankton changed the nitrogen composition. Phytoplankton (diatoms) increase in May and July with water temperature. In July and August, they decrease and other species (green algae and dinoflagellate) appear. Our observation shows that bottom material includes large amounts of organic matter that originated from phytoplankton. This is the main cause of decreased dissolved oxygen. To understand water quality in reservoirs, internal production and variation of phytoplankton is important.

Key Words : phytoplankton, dissolved oxygen, internal production, kinokawa river, long-term monitoring

\section{1. はじめに}

これまで, 都市化や産業の発達により, 河川に流入す る栄羑塩や有機物の負荷が増大し, 水域の環境が大きく 変化してきた. とくに, 貯水池やダムなどの人工的な停 滞水域では, 水の華や赤潮の発生などの水質の悪化が顕 在化している. しかし, 一方で, 人為的な影響の少ない 山地上流域においても水質悪化が進んでいることが重要 な問題として注目を浴びてきている. その原因として, 土砂流入に伴う土粒子に含まれる窒素・リンの流入や枯 葉などの植物残涬の有機物分解による栄養塩回帰が考え
られる1）2．つまり，このような状況は, 停滞水域の存 在自体が物質移動を抑制するために, 自然発生的に生じ る水質変化といえる.

山地上流に位置するダムや貯水池は，水質変化に与え る人為的な影響要因がないと考えられていたため, これ まであまり着目されていなかった. しかし, 貯水池やダ ムの多くは山地上流に位置しており，人為的影響の少な い場所における水質変化を考えることは，流域全体の水 質・水量・生態系バランスなどの環境変化を考える上で 重要である. また, 物質循環の観点から, 陸上の停滞水 域における物質貯留の影響が大きいことが報告されてお $り^{3)}$ ，一つ一つの水域における栄養塩収支を正確に見積 


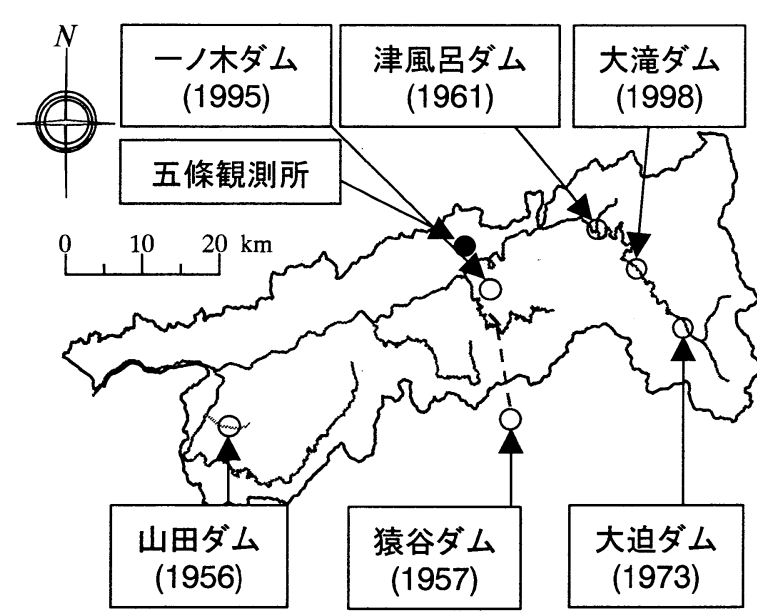

図-1 紀ノ川流域図とダムの位置 （括弧内はダムの建設完成年）

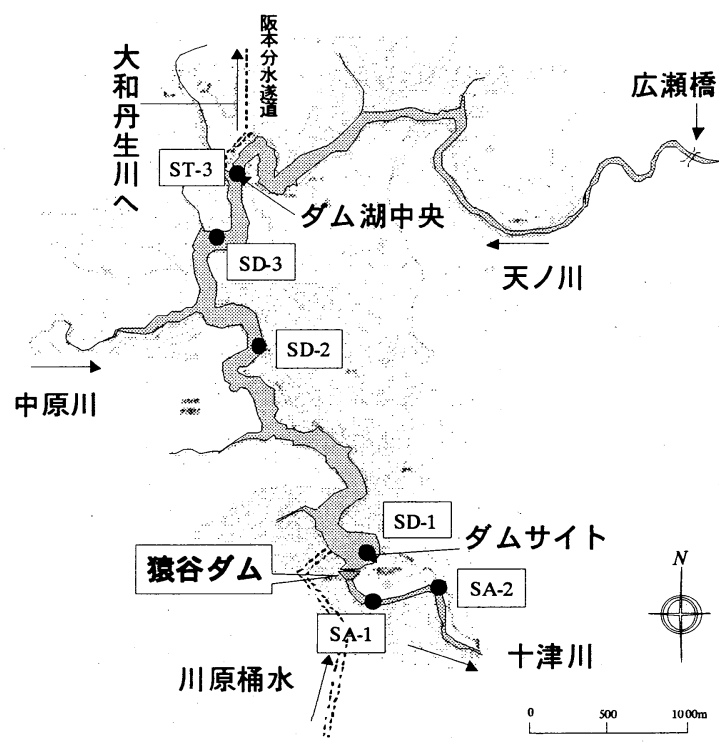

図-2 猿谷ダム流域の地図

もることが重要である．そのためには，まず，観測デー 夕から水質変化とその現状を知ることが必要である.

また, 近年, 数多くの生態系・水質モデルが開発され ている. モデルと観測との情報補間はまさに車の両輪で あり, 現場における長期間の水質・植物プランクトンの デー夕は貴重である. 本研究では, 十津川上流の猿谷ダ ムにおいて1976年以降継続的に観測されている水質デー 夕を整理し，また，底質中のクロロフィルaを分析し， 水質環境の変化と植物プランクトンの関係に焦点をおい て考察を行う.

\section{2. 流域・調査の概要}

\section{（1）猿谷ダムおよび流域の概要}

猿谷ダムは奈良県大塔村に位置し, 貯水容量 $23,300,000 \mathrm{~m}^{3}$ (有効貯水量 $17,300,000 \mathrm{~m}^{3}$ ) の貯水用ダ ムである (図-1 参照) ${ }^{5)}$. 標高は約700 $\mathrm{m}$ であり, 熊野 川河口より約 $100 \mathrm{~km}$ 上流に位置している. 猿谷ダムは, 自然流域界からみると新宮川水系に含まれるが，紀ノ川 の各種用水を補うため, 阪本分水隧道を通じて, 一部

（最大 $16.7 \mathrm{~m}^{3} / \mathrm{s}$ ）を紀八川水系である大和丹生川に導 水している (図-2 参照). そのため, 紀ノ川流域に含 められる. なお，猿谷ダムから直接下流の十津川に流れ る維持水量は $0.95 \mathrm{~m}^{3} / \mathrm{s}$ である. なお, ダムの回転率は 6〜 7 回/年程度である.

ダムの形状は南北方向に細長い形状（約 $4.5 \mathrm{~km} ）$ をし ており, 南端にダム提体があり, 提体部における水深が 最も深い（有効水深 $24 \mathrm{~m}$ ）. ダムの建設完成年は 1957 年 であり, 紀ノ川流域に建設されている6つのダムの中で は山田ダム（1956年建設完成）についで古い（図-1 参 照）。管理は国土交通省が行っている. 流域の土地利用 は大部分が森林であり, 天ノ川・中原川周辺にいくつか の建物があるが，ダム湖内の水質に対する人為的影響は 低いと考えられる.

\section{（2）長期水質観測の概要}

水質調査は，国土交通省が実施している ${ }^{4)}$ 。考察を 行った期間は, 水質調査が始まった1976から2002年まで の27年間である. 調査項目は硝酸態窒素 $\left(\mathrm{NO}_{3}{ }^{-}{ }^{-} \mathrm{N}\right)$, 亜硝 酸態窒素 $\left(\mathrm{NO}_{2}{ }^{-}-\mathrm{N}\right)$, アンモニア態窒素 $\left(\mathrm{NH}_{4}{ }^{+}-\mathrm{N}\right)$, 全空素 $(\mathrm{T}-\mathrm{N})$ ，オルトリン酸態リン $\left(\mathrm{PO}_{4}{ }^{3-}-\mathrm{P}\right)$, 全リン $(\mathrm{T}-\mathrm{P})$, ク ロロフィルa (Chl.a), 溶存酸素(D0), 植物プランクトン 個体数・種類である. 基本的に毎月調査が行われている が，測定項目によっては年数回のデータもある. 採水は, ダム内の「ダムサイト」,「ダム湖中央」, およびダム に流入する天ノ川の「広瀬橋」の計 3 地点で行われてい る (図-2 参照)．採水層は表層 $(0.5 \mathrm{~m})$, 中層, 底層 （底面+ $1 \mathrm{~m} ）$ の 3 層である. ダムサイトとダム湖中央 の水深は季節毎に変化するが，ダムサイトでは $30 〜 40 \mathrm{~m}$, ダム湖中央では10〜20 mである. また, エクマンバージ 式採泥器を用いて湖底面から約 $0.1 \mathrm{~m}$ 深さの採泥が実施 され, 強熱減量 (IL), 全窒素(T-N), 全リン (T-P), 化学 的酸素要求量 (COD) が分析されている. デー夕は, 2002 年を除き紙媒体形式で保存されているため, データ入力 を行った.

\section{（3）2004年1月21日の調查概要}

上記の調查とは別に，2004年 1 月21日に現地調査を実 施した. 採水は, ダム下流の渓流 $(S A-1,2)$, ダム湖内 (ST-3，SD-1, 2,3） で害施した. SA地点ではそれぞれ 1 サンプル，ST・SD地点ではそれぞれ上層と下層（底面十 $1 \mathrm{~m} ）$ の 2 層で採水を行った. なお, SD-1地点では, 他 の地点より水深が深いため, 上層, 中層, 下層で採水を 行った. なお, 水質分析方法の詳細は石塚ら ${ }^{5)}$ に詳しい. 


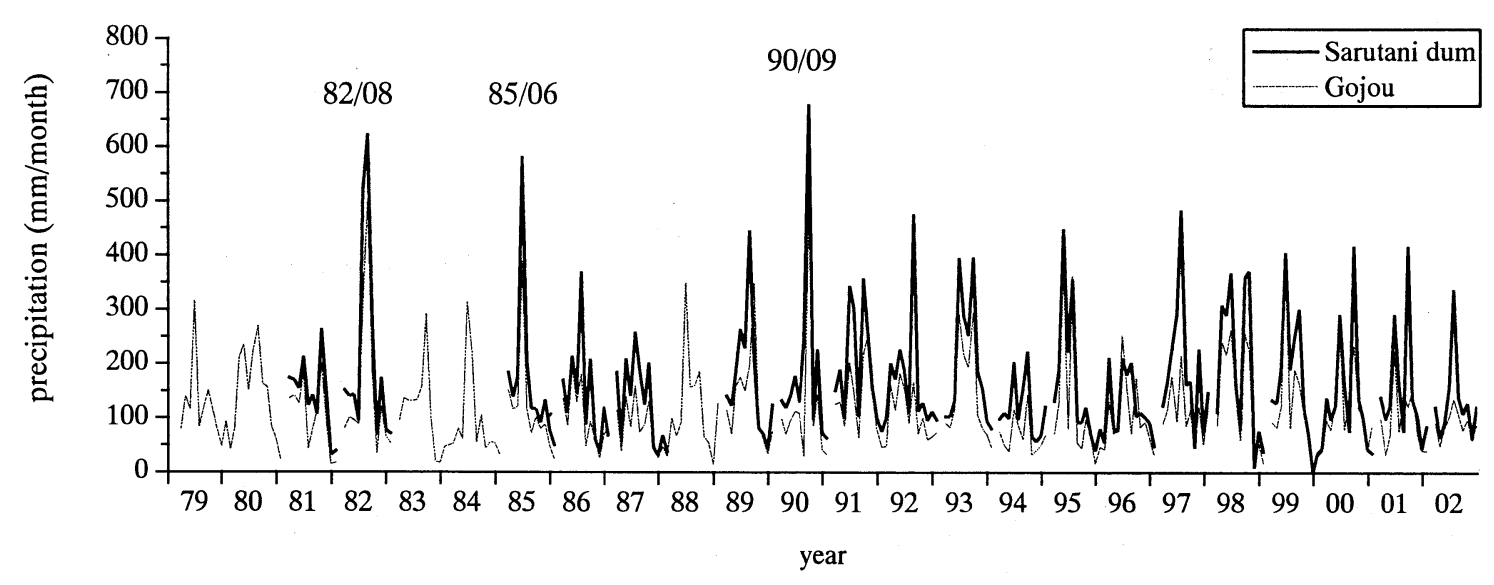

図-3 奈良県五條市（AMeDASデータ）と猿谷ダムにおける降水量の長期変化（1979〜2002年）, 猿谷ダムの観測デー夕は一部欠測

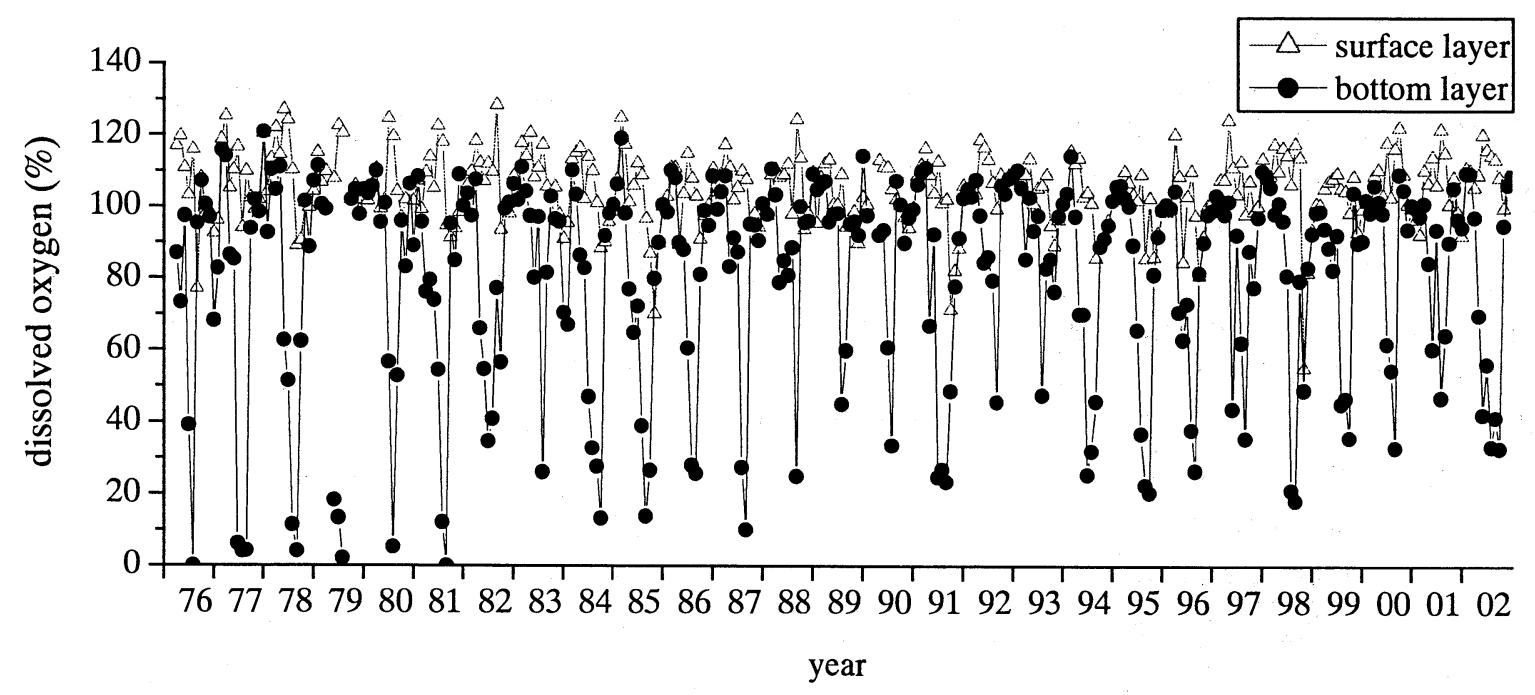

図-4 ダムサイトの表層と底層における溶存酸素濃度の長期変化（1976～2002年）

\section{3. 長期水質データの結果}

\section{（1）降水量・気温の長期変化}

図-3 は1979〜2002年の猿谷ダムおよび奈良県五條市 における月降水量を示す．猿谷ダムの年平均降水量は約 $1902 \mathrm{~mm} / \mathrm{yr}$ である4). 1990年以前に約600 mm/monthの降 雨が 3 回記録されているが，それ以降，大雨は観測され ていない. また，五條市の降水量の季節変化をみると， 6 月と 9 月の降水量が多い. また，猿谷ダムにおける気 温変化（1981～2002年）をみると，8月が最も高く $\left(23.3{ }^{\circ} \mathrm{C}\right) ， 2$ 月が最も低い $\left(0.3{ }^{\circ} \mathrm{C}\right){ }^{4)}$.

\section{（2）溶存酸素濃度の長期変化}

ダムなどの停滞水域における水質変化の中で, 水中の 溶存酸素濃度の変化は生物活動の維持や嫌気的作用によ る物質の溶出などに対して重要である. 図-4 は溶存酸 素濃度の長期変化を示す. 最も注目すべき点は, ダムの 建設完成年から 20 年後の1976年の時点において，すでに 夏季に底層が貧酸素状態にあることである. ダム流域の 土地利用の大部分が森林であることを考えると, 自然由 来の栄盖告供給が水質に与える影響は非常に大きいこと が分かる. 図-5 はダムサイトにおける表層と底層の水 温の季節変化を示す． 4 月から10月にかけて水温差が生 じ，気温が最も高くなる 8 月の水温差が最も大きく $9.6{ }^{\circ} \mathrm{C}$ となる. また, 植物プランクトン個体数が増加す る 3〜 9 月に溶存酸素濃度が110 120\%に増加し, ま た, $\mathrm{pH}$ 5〜8月に8.0程度と若干増加しており（その 他の月は7.5）, 光合成が生じていることがわかる. 


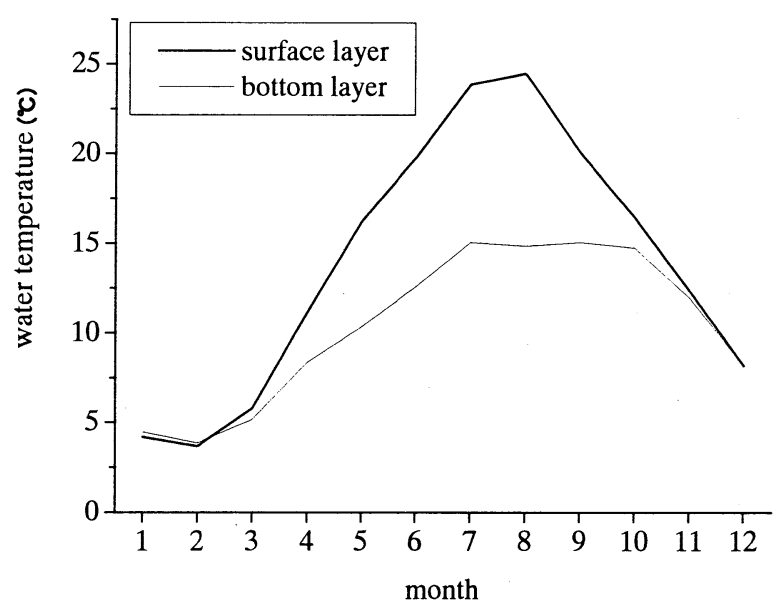

図-5ダムサイトにおける表層と底層の水温の季節変化

（1976～2002年）

\section{（3）底質の長期変化}

図-6 は, 底泥のT-N, T-P, COD, 強熱減量 (IL) の長 期変化を示す．底質は 1981 年以降, 年 2 回または 1 回の 頻度で観測が行われており，21年間の観測データがある （ただし，ダムサイトにおける採泥は1995年まで実施）。 ILについて, 紀ノ川大堰のデータ（10.7％（8月）, $6.7 \%$ （1月）） ${ }^{5)}$ と比較すると, 猿谷公んにおいて, 底泥の有機物含有量は多いことがわかる.このことは, 底層における夏季の貧酸素化の原因と考えられる. また， 長期変化については特徵的な変化の傾向はみられなかっ た. 底泥の採取深が $0.1 \mathrm{~m}$ であることを考えると，観測 デー夕は数年間の平均的な変化を示しているといえる. つまり, ダム流域の大きな環境変化がないことを考える と, 栄養塩供給量と内部生産量, 沈降・分解量がバラン スしている可能性が考えられる。しかし，1996年と1999 年に底泥の浚渫をダム湖中央付近で実施しており，その 年に底質の改善がみられる.しかし， $1 \cdot 2$ 年後には元 の值に回復している.
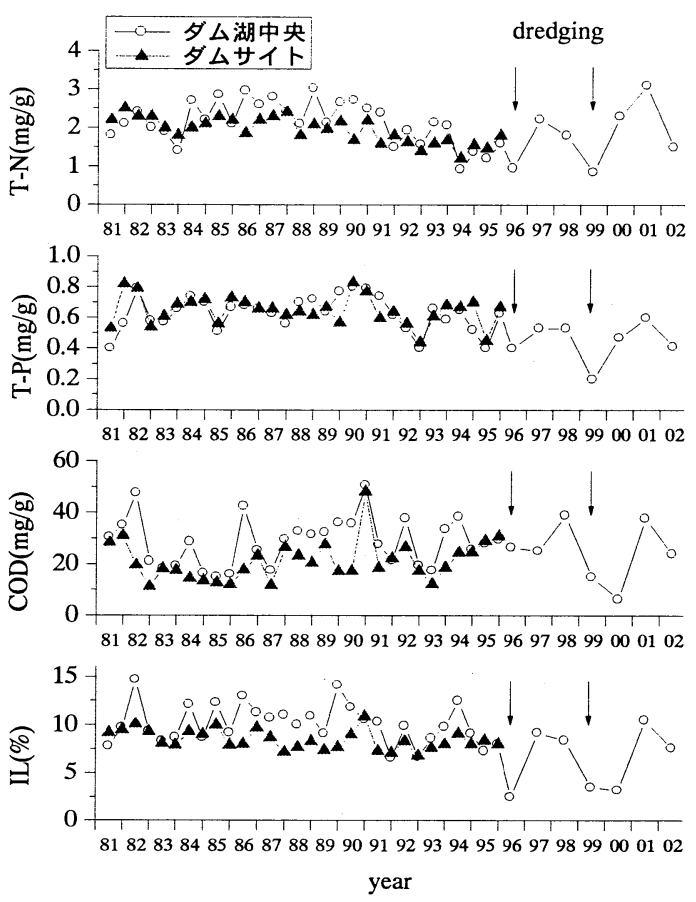

図-6＼cjkstart底泥のT-N, T-P， COD, 強熱減量の長期変化 (1981 2002年)

\section{（4）窒素の長期変化}

図-7 は，ダム湖中央と広瀬橋における窒素成分の時 間変化を示す。ここで，有機態窒素 (ON) は, $\mathrm{T}-\mathrm{N}$ と溶 解性無機態窒素 3 成分との差から求めた. したがって, ONには粒子性有機物と溶解性有機物が含まれる. 特徵的 な結果は, ダムに流入する渓流水 (広瀬橋) とダム内の $\mathrm{T}-\mathrm{N}$ がほぼ同じ值を示す点である．また，広瀬橋におい て溶解性成分の分析が行われた1990年以前について，TNに対する0Nの比をとると, 広瀬橋, ダム湖中央, ダム サイトにおいてそれぞれ，41，54，65％であり，全窒 素に含まれる有機態窒素がダム内において増加している ことがわかる.これは，ダム内における内部生産により， $\mathrm{NO}_{3}{ }^{-}$-Nが生体内に取り込まれている結果を示している.

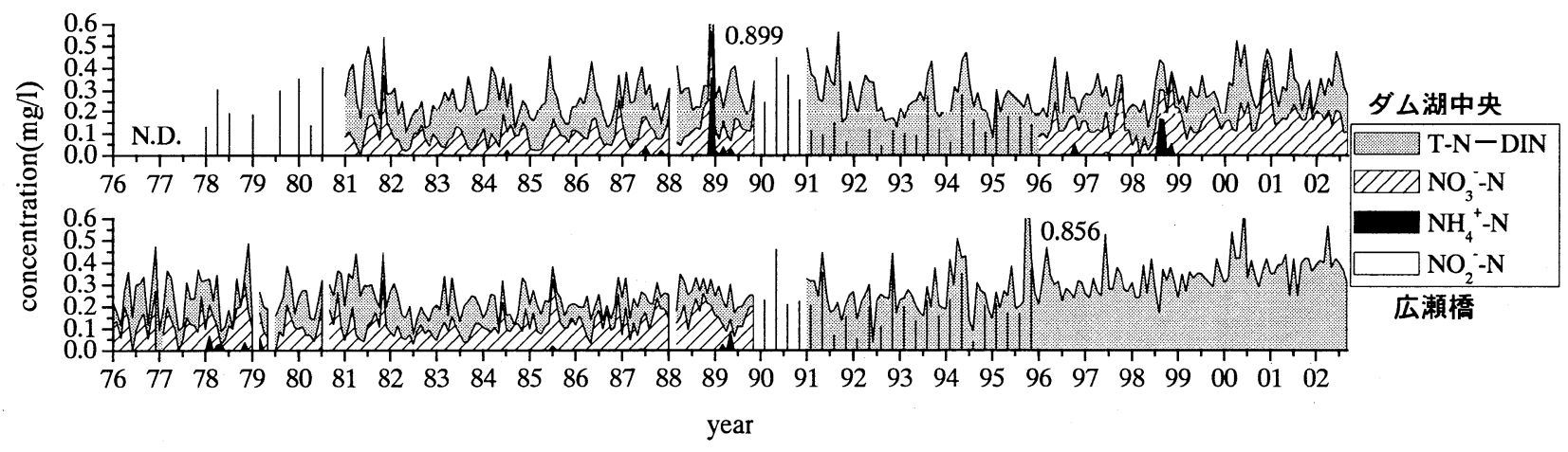

図-7 ダム湖中央と広瀬橋の表層における窒素の長期変化（1976〜2002年）

（図中の棒グラフの説明 : 78〜80年，90年はT-N（年4回調査），91〜95年は $\mathrm{NO}_{3}{ }^{-}-\mathrm{N}, \mathrm{NO}_{2}{ }^{-}-\mathrm{N}, \mathrm{NH}_{4}{ }^{+}-\mathrm{N}^{-}{ }^{-1}$ 表す. 1996〜2002年の広瀬橋における $\mathrm{NO}_{3}{ }^{-}-\mathrm{N}, \mathrm{NO}_{2}{ }^{-}{ }^{-} \mathrm{N}, \mathrm{NH}_{4}{ }^{+}-\mathrm{N}$ デー夕は無し. ) 


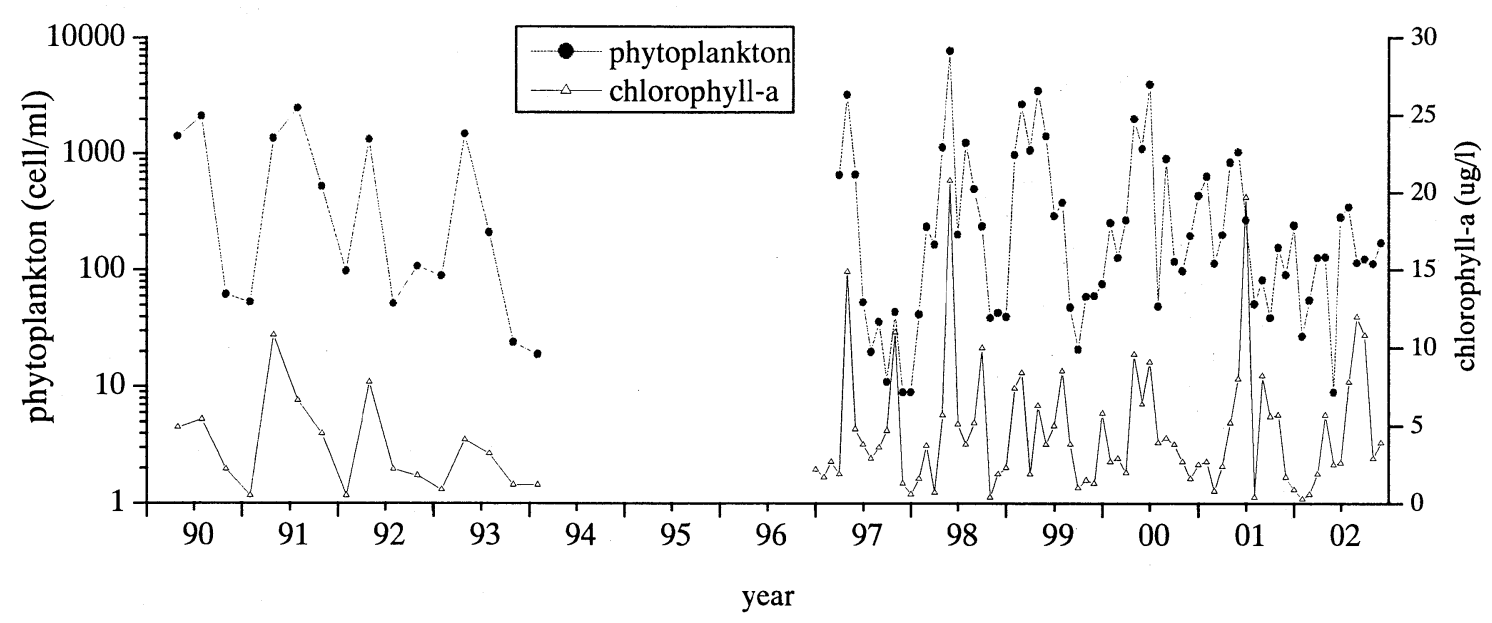

図-8ダムサイトの表層におけるクロロフィルaと植物プランクトン個体数の長期変化（1990～1994年，1997～2002年）

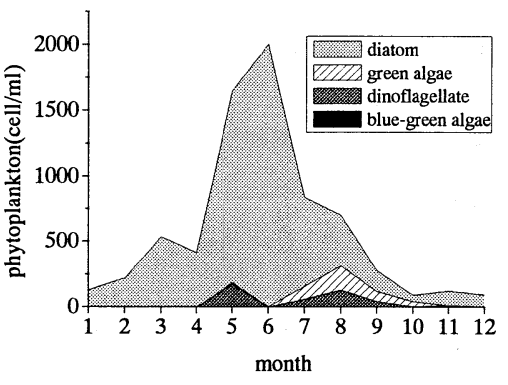

(a) ダムサイト

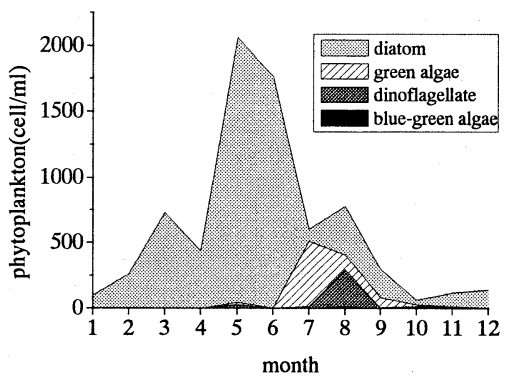

(b) ダム湖中央

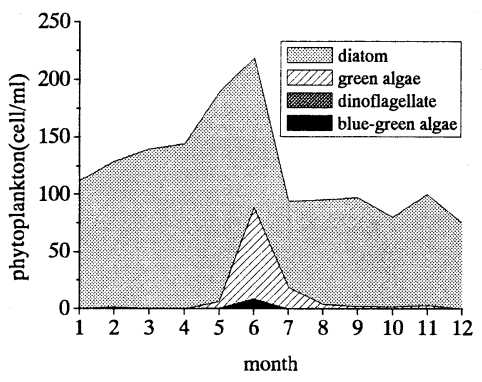

(c) 広瀬橋

図-9＼cjkstart各地点の表層における植物プランクトン個体数と種構成の季節変化（使用データ：1990～1994年，1997〜2002年）

広瀬橋とダムサイトにおけるT-Nは，平均的にみると $0.2 \mathrm{mg} / \mathrm{l}$, 多い月で約 $0.4 \mathrm{mg} / 1$ であり, 自然由来の窒素 供給が大部分を占めるために高い值ではない（紀ノ川大 堰直上において平均 $\left.0.8 \mathrm{mg} / \mathrm{l}^{6)}\right)$ ．また, ダム湖中央に おいて浚渫が開始された1996年以降，T-N中の溶解性無 機態窒素の割合が浚渫以前と比較して，増加しているこ とがわかる.ここ数年の夏季の底層における溶存酸素濃 度の回復とあわせて考えると（図-4 参照），内部生産 量が以前よりも減少し, ダム上流から供給される溶解性 窒素の中で, 生物活動に利用される量が減少した可能性 が考えられる. しかし，近年における広瀬橋でのT-Nの 増加やクロロフィルaやプランクトン個体数の長期デー 夕に特徵的な変化がみられないことから（図-8 参照）， その詳細は明らかではない，また，表層においてアンモ 二ア態窒素が観測されている年があるが，この理由は明 らかでない.

\section{（5）植物プランクトンの季節変化}

図-9 は, 各地点における植物プランクトンの個体数 とその種構成の季節恋化を示す．ダム内 2 地点における 変化をみると，4月から 5 月にかけて植物プランクトン 個体数が急激に増加しており, 珪藻プランクトンのブ
ルーミングが生じている. しかし，7月以降，植物プラ ンクトン個体数は急激に減少し, 10月以降, ダム湖内で は約 $100 \mathrm{cell} / \mathrm{ml}$ となる. 一方, 広瀬橋は猿谷ダムに流 入する渓流に位置しており，わずかではあるが $5 \cdot 6$ 月 に珪澡プランクトン個体数が増加しており, 春季の水温 増加に伴いダム内と同様の時間変化を示す.

また, 種構成をみると, ダム内 2 地点では, 7 ～10月 に, 渦鞭毛澡類と緑藻類が増加し, 珪藻プランクトンの 割合が多い冬季・春季と比較して, 種構成の変化がみら れる. 広瀬橋では， $6 \cdot 7$ 月に緑睰類が増加しており， 6 月にはわずかに藍澡類も観察されている．また，広瀬 橋では, 渦鞭毛藻類は全く観測されていない.

植物プランクトンの優占種は, ダム湖中央とダムサイ トではほぼ同じ種類であり, 珠藻類はAsterionella formosa, Fragilaria spp., Melosira distans, 緑藻類 はEudorina elegans, Sphaerocystis schroeteriであっ た.これに対して, 広瀬橋では珠藻類のCymbella spp., Navicula spp.が優先的であり, ダム湖内と種類が異な る点が特徴的である.

\section{4. ダム内とその下流における有機物量の変化}



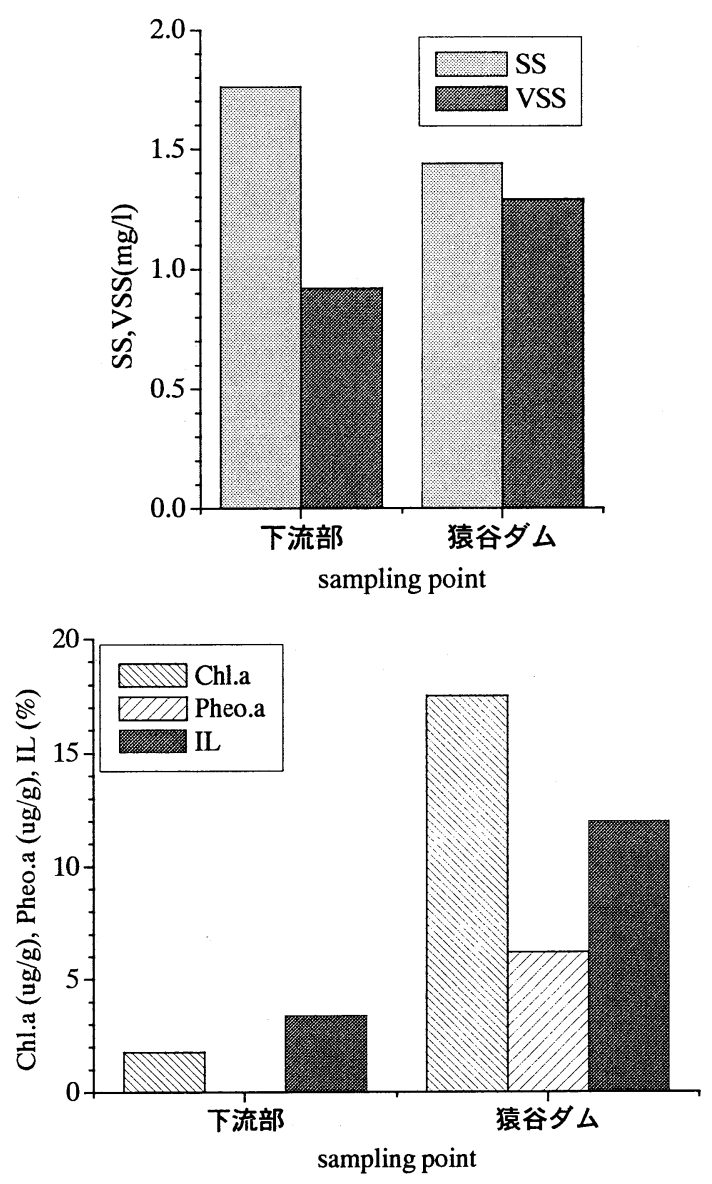

図-10 ダム内とその下流における水中の粒子性物質 （上段）および底質（下段）

前章ではダム内の水質の長期変化を示したが，猿谷ダ ムのようなダムに流入する渓流水の栄養塩濃度が低い停 滞水域における水質を考えるためには，有機物の組成お よび停滞水域とその下流における変化を知ることが重要 である.ここでは，国土交通省の定期観測では測定が行 われていない水中のSSの有機物量（VSS）と底質中のク ロロフィルaおよびフェオフィチンa量の測定結果を示し て, ダム内とその下流における有機物量の変化から, 山 地上流に位置する夕゙ムにおける水質変化の特徵を調べる.

図-10 は，ダム内とその下流における水中の粒子性物 質および底泥中の有機物量を示す．ここで，ダム内の データはSD-1〜3, ST-3のデータの平均值を示す. 特徵 的な結果は, ダム内の底質にクロロフィルaとフェオ フィチンaが多く含まれることである.このことから， ダム内では, 植物プランクトンによる内部生産が多く, 底質中に内部生産起源の有機物が植物残涬以外にも多く 合まれるここが分かる. また, ダム内の底泥中の有機物 量はその下流よりも多いことが分かる.

観測が冬季に実施されたために，ダム内の水温は鉿直 一様に分布しており（SD-1地点において, 表層と底層と もに水温 $4^{\circ} \mathrm{C}$ ), また, 降水量も少ないことから, 水中 に含まれるSSはダム内とその下流ともに少なかった.こ こで, ダム内とその下流におけるSSとVSSの差をみると,
わずかではあるが，ダム内ではSSに占める有機物量が多 いことが分かる. 逆に, ダムの下流では, SS中の無機物 が多いことが分かる.

\section{5. おわりに}

猿谷ダムでは, ダム建設後の 20 年経た1976年時点で, すでにダム底層において貧酸素現象が生じており, 自然 由来の土砂流入や植物残涬による間接的な栄荃塩供給が ダム水質に与える影響が大きいことが明らかとなった. また, 底泥には植物プランクトン由来の有機物が含まれ ており, 流れの停滞による内部生産の影響があるという 結果が得られた.

一般に, ダム貯水池などの停滞水域では, 窒素・リ ン・ケイ素等の栄養塩の流入と流れの停滞にともなう夏 季の水温上昇・水温成層により, 植物プランクトンが增 殖し, その後, 無光層への死骸の沈降と分解によって底 層の溶存酸素濃度が減少する. 本研究が対象とした猿谷 ダム流域は, 人為的影響が少ないが, 水質の長期変化を みると, わずかな栄養塩の供給により, 夏季の底層にお いて貧酸素化が生じている結果が示された.このことは, 上流から運ばれる植物残涬以外にもダム内の内部生産に よるところが大きく, 植物プランクトンの変化動向を詳 細に明らかにすることがダムの水質管理に重要といえる.

謝辞 : 猿谷ダムの長期水質データは, 国土交通省猿谷ダ 厶管理所管理支所 阿部宏行様, 渡辺俊夫様, 紀ノ川ダ 么統合管理事務所 本勝盛雄様, 和歌山河川国道事務所 和佐喜平様, 吉安勇介様のご協力で提供いただいた. ま た, 水質分析には, 科学研究費補助金 (若手 (B), 15760380, 代表 : 石塚正秀), および和歌山大学大学特 別経費(代表 : 石塚正秀)の援助を得たことを示す.

\section{参考文献}

1）解也：ダム貯水池からの排少と排少時の放流水質管理，ダム技 術, No.127, pp. 30-38, 1997.

2）道奥康治 : 流域からの植生残渣による貯水池の有機污濁 に関する研究, 文部科学省研究成果報告書 (萌芽研究), 課題番号14655177, 98p, 2004.

3) USGS : Magnitude and Significance of Carbon Burial in Lakes, Reservoirs, and Northern Peatlands, U. S. Geological Survey Fact Sheet FS-058-9.9, 19.99.

4）国十交通省: 猿谷ダム水質調查業務報告書，1976 2002.

5）石塚正秀・寺本健士 - 紺野雅代 - 并伊博行 - 平田健正： 紀ノ川下流の淡水域・汽水域における冬季から夏季の栄 盖塩・植物プランクトンの現地調查, 水工学論文集, 第 49巻（印刷中） .

(2004. 9.30 受付) 